\title{
Analisis Pengaruh Kurs Rupiah, Laju Inflasi, Jumlah Uang Beredar dan Pertumbuhan Ekspor terhadap Total Pembiayaan Perbankan Syariah dengan Dana Pihak Ketiga sebagai Variabel Moderating
}

\author{
Syukuri Ahmad Rifai*, Helmi Susanti, Aisyah Setyaningrum \\ Institut Agama Islam Negeri Salatiga \\ syukuriahmadrifai@gmail.com
}

\begin{abstract}
The purpose of this study was to determine the effect of the rupiah exchange rate, inflation, money supply and the growth of exports to total Islamic banking financing by using thirdparty funds as a moderating variable. The population in this study is all Islamic banking in Indonesia both Islamic Banks or Business Unit of Sharia in 2007-2015. The sample is the entire population with time series data as much as 108 of data. The method used is multiple regression analysis. The results of this study showed that simultaneous variable rupiah exchange rate, inflation, the money supply and export growth significantly influence the total financing of Islamic banking in Indonesia. Meanwhile, third-party funds moderating influencesthe rupiah exchange rate, inflation and export growth to the total financing of Islamic banking in Indonesia.
\end{abstract}

Keywords: Rupiah Exchange Rate; Inflation; Money Supply; The Growth of Exports; ThirdParty Fund and Islamic Banking Financing

\begin{abstract}
Abstrak
Tujuan dari penelitian ini untuk mengetahui pengaruh kurs rupiah, inflasi, jumlah uang beredar dan pertumbuhan ekspor terhadap total pembiayaan perbankan syariah dengan menggunakan dana pihak ketiga sebagai variabel moderasi. Populasi dalam penelitian ini adalah seluruh perbankan syariah di Indonesia baik Bank Umum Syariah atau pun Unit Usaha Syariah tahun 2007-2015. Sampelnya adalah seluruh populasi dengan data time series sejumlah 108 . Metode yang digunakan adalah analisis regresi berganda. Hasil penelitian ini menunjukkan bahwa secara simultan variabel kurs rupiah, inflasi, jumlah uang yang beredar dan pertumbuhan ekspor berpengaruh signifikan terhadap total pembiayaan perbankan syariah di Indonesia. Sedangkan, dana pihak ketiga memoderasi pengaruh kurs rupiah, inflasi dan pertumbuhan ekspor terhadap total pembiayaan perbankan syariah di Indonesia.
\end{abstract}

Kata Kunci: Kurs Rupiah, Laju Inflasi, Jumlah Uang Beredar (JUB), Pertumbuhan Ekspor, Dana Pihak Ketiga (DPK) dan Pembiayaan Perbankan Syariah 


\section{PENDAHULUAN}

Indonesia dengan populasi penduduk sekitar 237.641.326 juta jiwa dimana $87,18 \%$ beragama Islam, memiliki potensi cukup besar untuk mengembangkan Industri Keuangan Islam. Ketertarikan dan perhatian masyarakat terhadap industri keuangan juga kian membaik. Berdasarkan data Statistik Perbankan Indonesia (SPI) hingga Januari 2016, jumlah industri Bank Umum Syariah (BUS) sebanyak 12 bank, Unit Usaha Syariah sebanyak 22 bank dan BPRS sebanyak 163 bank. Total aset khusus BUS dan UUS adalah Rp. 287.440 triliun, pembiayaan Rp. 197.913 triliun dan penghimpunan DPK perbankan syariah sebesar Rp. 229.094 triliun.

Salah satu fungsi bank syariah adalah menyalurkan dana dalam bentuk pembiayaan. Pembiayaan pada perbankan syariah memiliki perbedaan fundamental dengan kredit pada perbankan konvensional. Karakteristik yang paling membedakan adalah akad dan produk-produk pembiayaannya. Pembiayaan yang disalurkan oleh bank syariah tersebar dalam berbagai bidang usaha dan sektor ekonomi. Untuk melihat perkembangan pembiayaan perbankan syariah 2007-2015 dapat dilihat pada tabel berikut ini:

Tabel 1. Nilai dan Share Pembiayaan Perbankan Syariah terhadap Total Pembiayaan Perbankan Syariah di Indonesia Tahun 2007-2015

\begin{tabular}{lrrrrrr}
\hline Tahun & $\begin{array}{r}\text { Musyarakah } \\
\text { (miliar) }\end{array}$ & $\begin{array}{r}\text { Mudharabah } \\
\text { (miliar) }\end{array}$ & $\begin{array}{r}\text { Murabahah } \\
\text { (miliar) }\end{array}$ & $\begin{array}{r}\text { Lainnya } \\
\text { (miliar) }\end{array}$ & $\begin{array}{r}\text { Total Pembia } \\
\text { yaan (miliar) }\end{array}$ & $\begin{array}{r}\text { Market } \\
\text { Share (\%) }\end{array}$ \\
\hline 2007 & 3.289 & 4.686 & 13.340 & 1.056 & 27.944 & 2,67 \\
2008 & 6.116 & 6.518 & 19.810 & 1.653 & 38.195 & 3,00 \\
2009 & 6.134 & 9.142 & 24.245 & 2.673 & 46.886 & 2,50 \\
2010 & 7.593 & 12.420 & 31.108 & 4.680 & 68.181 & 2,00 \\
2011 & 9.077 & 16.295 & 46.161 & 10.611 & 102.655 & 3,98 \\
2012 & 22.298 & 10.904 & 67.725 & 16.638 & 147.505 & 4,23 \\
2013 & 35.057 & 12.629 & 104.718 & 20.490 & 184.122 & 4,80 \\
2014 & 42.830 & 13.802 & 112.288 & 18.964 & 199.330 & 4,89 \\
2015 & 54.033 & 14.906 & 117.777 & 17.177 & 203.894 & 4,61 \\
\hline
\end{tabular}

Sumber: Statistik Perbankan Syariah, 2007-2015 (diolah).

Berdasarkan data di atas, market share pembiayaan perbankan syariah di Indonesia sampai tahun 2015 masih dibawah 5\%. Padahal, pembiayaan merupakan fungsi dan produk untuk perluasan market share (Bank Indonesia, 2007-2015). Beberapa faktor yang mempengaruhi permintaan dan pemberian pembiayaan adalah tingkat kredit macet, dana himpunan masyarakat, kurangnya modal, nilai tukar rupiah, inflasi dan tingkat suku bunga (Herijanto, 2013: 144).

Salah satu faktor makro ekonomi adalah inflasi (proses meningkatnya hargaharga secara umum dan terus-menerus). Para ekonom Islam menyebutkan dampak inflasi antara lain: menimbulkan gangguan fungsi uang, melemahkan semangat menabung, meningkatkan kecenderungan berbelanja dan mengarahkan pada investasi non-produktif (Karim, 2007: 137). 
Berdasarkan data Badan Pusat Statistik (BPS), pada tahun 2008 inflasi di Indonesia mencapai tingkat $11,06 \%$. Hal ini disebabkan oleh naiknya harga pangan dunia karena gagal panen di Cina dan Rusia. Setelah tahun 2008, tingkat inflasi sangat fluktuatif dan inflasi tahun 2015 berada pada tingkat 3,35\% (BPS, 2007-2015). Menurut Kepala BPS Suryamin, bahwa untuk mengurangi dampak inflasi, Bank Indonesia terus mencermati berbagai risiko yang mempengaruhi perekonomian diantaranya perkembangan harga minyak dunia, nilai tukar, penyesuaian administered prices dan gejolak harga pangan (Suryowati, 2016).

Faktor makro ekonomi selain inflasi yang berpengaruh adalah perkembangan jumlah uang beredar (JUB) (Halim, 2013). Besar kecilnya JUB akan mempengaruhi daya beli riil masyarakat dan juga tersedianya kebutuhan masyarakat (Setyawan $\&$ Baratakusumah, 2005: 11). Jumlah uang beredar yang ada di tangan masyarakat harus berkembang secara wajar, agar memberikan pengaruh positif terhadap perekonomian. Namun, jika JUB meningkat tajam akan memicu inflasi dan berpengaruh negatif terhadap perekonomian (Untoro, 2007).

Faktor lain yang mempengaruhi total pembiayaan perbankan syariah adalah nilai kurs rupiah terhadap dollar AS. Kurs merupakan tingkat harga pertukaran dari satu mata uang ke mata uang lainnya dan digunakan dalam berbagai transaksi (Karim, 2007: 157). Nilai kurs rupiah pada Maret 2015 mengalami pelemahan yaitu melampui Rp 13.000 per dolar, nilai ini merupakan nilai terendah sejak krisis moneter 1998 (Junaedi, 2015). Seperti yang dijelaskan oleh Solikin M. Juhro, Direktur Departemen Kebijakan Ekonomi dan Moneter BI, bahwa hal tersebut dapat terjadi disebabkan oleh pengaruh global dan domestik. Fenomena penguatan USD secara global mempengaruhi sentimen pasar, hal ini disebabkan oleh perbaikan ekonomi Amerika paska krisis keuangan global. Sedangkan dari sisi domestik, sebagai negara yang sedang membangun, Indonesia masih mengalami deficit transaksi berjalan (current Account Deficit/CAD) yang cukup besar (Gerai Info Bank Indonesia, 2015)

Turunnya kurs rupiah (depresiasi) dan naiknya kurs rupiah (apresiasi) mempengaruhi ekspor suatu negara. Saat nilai tukar rupiah terhadap dollar mengalami depresiasi total, maka ekspor suatu negara akan naik. Naiknya pendapatan eksportir akan meningkatkan pendapatan domestik bruto negara tersebut (Samuelson \& Nordhaus, 1997: 182). Ketika pendapatan ekspor meningkat, para eksportir berusaha melakukan pembiayaan di bank sehingga mempengaruhi penyaluran pembiayaan bank syariah (Lie \& Malelak, 2015: 69).

Salah satu faktor penting dalam menjalankan fungsi penyaluran dana adalah aspek penghimpunan dana. Kunci keberhasilan manajemen bank syariah ditentukan oleh bagaimana bank dapat merebut hati masyarakat, sehingga perannya sebagai $f$ nancial intermediary berjalan dengan baik (Antonio, 2001: 41). Bagaimana bank melayani pihak yang kelebihan dana dan menyimpan uangnya dalam bentuk giro wadiah, deposito mudharabah, tabungan wadi'ah maupun tabungan mudharabah, serta melayani kebutuhan uang masyarakat melalui pemberian pembiayaan. Beberapa variabel di atas merupakan faktor-faktor yang mempengaruhi besar kecilnya jumlah penyaluran pembiayaan pada bank syariah. 


\section{LANDASAN TEORI}

\section{Pengaruh Ekonomi Makro Secara Umum Terhadap Pembiayaan}

Lemah dan kuatnya lembaga keuangan syariah disebabkan oleh indikator makro ekonomi yang mempengaruhi stabilitas sistem keuangan (Herijanto, 2013: 148). Menurut Deputi Komisioner Pengawasan Perbankan OJK Irwan Lubis, bahwa kegiatan perbankan akan mengikuti perkembangan perekonomian yang sedang berlangsung baik di tingkat regional, nasional, maupun internasional (Setiawan, 2016). Beberapa faktor yang mempengaruhi permintaan dan pemberian pembiayaan adalah tingkat kredit macet, kurangnya modal, dana himpunan masyarakat, nilai tukar rupiah, inflasi dan tingkat suku bunga (Herijanto, 2013: 144). Selain itu, penyaluran pembiayaan harus dianalisis sesuai fakta dan informasi yang tepat, guna meminimalisir krisis perbankan yang dimulai dari penyaluran kredit dengan risiko berlebihan (over leverage) dan economic shock (perubahan besar pada ekonomi makro) (Herijanto, 2013: 158). Berdasarkan penjelasan di atas, faktor makro ekonomi yang mempengaruhi pembiayaan perbankan syariah di Indonesia yaitu kurs rupiah, laju inflasi, jumlah uang beredar dan pertumbuhan ekspor.

\section{Kurs Rupiah}

Menurut Halwani (2005: 157), nilai tukar mata uang merupakan perbandingan nilai dua mata uang yang berbeda atau disebut kurs. Menurut Greenwald yang dikutip oleh Karim (2007: 157) dalam Encyclopedia of Economics, nilai tukar mata uang adalah catatan (quotation) harga pasar dari mata uang asing (foreign currency) dalam harga mata uang domestik (domestic currency) atau resiprokalnya (harga mata uang domestik dalam mata uang asing).

Perkembangan sistem nilai tukar mata uang menurut Halwani (2005: 158160), yaitu: sistem nilai tukar standar emas (penetapan nilai tukar mata uang dalam berat emas tertentu), sistem nilai tukar tetap (semua transaksi mata uang menggunakan kurs yang ditetapkan oleh bank sentral), sistem nilai tukar pengawasan devisa (negara tidak memiliki cadangan devisa yang cukup untuk menutupi defisit neraca pembayaran yang terus menerus), sistem nilai tukar tambatan (mata uang domestik dikaitkan dengan mata uang asing dan tingkat nilai tukarnya merupakan penurunan dari nilai tukar mata uang asing yang dijadikan tambatan) dan sistem nilai tukar mengambang (tingkat nilai tukar dibiarkan menurut keseimbangan permintaan dan penawaran mata uang asing).

Menurut Karim (2007: 167-175), penyebab fluktuasi nilai tukar mata uang dalam pembahasan nilai tukar menurut Islam akan dipakai dua skenario, yaitu:

1. Skenario satu, terjadi perubahan harga di dalam negeri yang mempengaruhi nilai tukar mata uang (faktor luar negeri dianggap tidak berubah/berpengaruh). Penyebab fluktuasi mata uang di dalam negeri dikelompokkan menjadi dua, yaitu Natural exchange rate fluctuation (fluktuasi nilai tukar akibat perubahan permintaan dan penawaran agregatif) dan Human error exchange rate fluctuation terdiri dari Corruption \& bad administration (korupsi dan administrasi yang buruk akan menaikkan harga), excessive tax (pajak penjualan yang sangat tinggi akan meningkatkan harga jual barang dan jasa secara agregatif) serta excessive seignorage (uang dicetak melebihi kebutuhan sektor riil sehingga harga naik). 
2. Skenario dua, terjadi perubahan harga di luar negeri (faktor di dalam negeri dianggap tidak berubah/berpengaruh). Perubahan harga diluar negeri bisa digolongkan karena dua sebab yaitu non engineered/non-manipulated changes (kenaikan perubahan angka terjadi bukan disebabkan manipulasi oleh pihak-pihak tertentu) dan engineered/manipulated changes (perubahan yang terjadi disebabkan manipulasi oleh pihak tertentu untuk merugikaan pihak lain).

\section{Hubungan Kurs Rupiah Terhadap Pembiayaan Perbankan}

Pengaruh kurs terhadap kondisi makro ekonomi berhubungan dengan tingkat harga yang berlaku dan mempengaruhi perilaku nasabah dalam menabung serta permintaan pembiayaan. Mankiw (2001: 125) menyatakan jika kurs riil tinggi, barangbarang dari luar negeri relatif lebih murah dan barang-barang domestik lebih mahal dan sebaliknya. Jika kurs rupiah melemah terhadap mata uang negara lain, maka barang produksi atau jasa yang dihasilkan negara itu menjadi lebih mahal berdasarkan mata uang negara lain tersebut. Akibatnya, permintaan barang atau jasa menurun dan dapat terjadi substitusi yang menekan permintaan. Saat permintaan menurun, produsen akan menurunkan pasokan dan tercapai keseimbangan baru. Pengurangan pasokan dilakukan dengan mengurangi produksi sehingga ekonomi mengalami perlambatan. Akibatnya kebutuhan dana untuk modal kerja maupun investasi berkurang, sehingga bank kesulitan menyalurkan pembiayaan dan sebaliknya (Cahyono, 2009: 31-32).

\section{Inflasi}

Menurut Karim (2007: 135) inflasi adalah kenaikan tingkat harga barang/komoditas dan jasa secara umum selama periode waktu tertentu. Inflasi dapat dianggap sebagai fenomena moneter karena terjadi peningkatan nilai unit penghitungan moneter terhadap suatu komoditas. Sebaliknya, jika terjadi penurunan unit penghitungan moneter terhadap barang/komoditas dan jasa disebut deflasi (deflation). Inflasi diukur dengan tingkat inflasi (rate of inflation). Menurut Sukirno (2004: 27) tingkat inflasi adalah presentase kenaikan harga-harga pada suatu tahun tertentu berbanding dengan tahun sebelumnya. Penggolongan inflasi menurut tingkat keparahannya dalam Karim (2007: 137), yaitu sebagai berikut:

1. Moderated inflation; cirinya adalah kenaikan tingkat harga yang lambat.

2. Galloping Inflation; inflasi terjadi pada tingkat $20 \%$ sampai $200 \%$ per tahun.

3. Hyper Inflation; inflasi terjadi pada tingkat yang sangat tinggi yaitu jutaan sampai triliunan persen per tahun.

Penyebab terjadinya inflasi menurut Karim (2007: 138) yaitu, Natural Inflation dan Human Error Inflation (Natural Inflation adalah inflasi yang terjadi karena sebab-sebab alamiah dan manusia tidak dapat mencegahnya. Human Error Inflation adalah inflasi terjadi karena kesalahan manusia), Actual/ Anticipated/ Expected Inflation dan Unanticipated/ Unexpected Inflation (Excepted Inflation memiliki ciri tingkat suku bunga pinjaman riil sama dengan tingkat suku bunga pinjaman nominal dikurangi inflasi. Unexpcted Inflation terjadi saat tingkat suku bunga pinjaman nominal belum merefleksikan kompensasi terhadap efek inflasi), Demand Pull/ Cost Push Inflation, (Demand Pull Inflation diakibatkan oleh perubahan permintaan agregat barang dan jasa. Cost Push Inflation adalah inflasi yang terjadi karena perubahan 
penawaran agregat barang dan jasa), Spiralling Inflation (Inflasi yang diakibatkan oleh inflasi yang terjadi sebelumnya dan begitu seterusnya), Imported Inflation dan Domestic Inflation (Imported Inflation adalah inflasi di negara lain yang ikut dialami oleh suatu negara karena harus menjadi price taker dalam pasar perdagangan internasional. Domestic Inflation merupakan inflasi yang hanya terjadi di dalam suatu negara yang tidak mempengaruhi negara-negara lainnya).

\section{Hubungan Inflasi dengan Pembiayaan Perbankan}

Inflasi mencerminkan stabilitas ekonomi, secara teori inflasi dapat melemahkan semangat menabung masyarakat, meningkatkan kecenderungan berbelanja dan mengarahkan investasi pada hal-hal yang non-produktif (Karim, 2007: 137). Di sisi lain, ini berarti bahwa masyarakat beranggapan tidak ada perbedaan bonus wadi'ah dan bagi hasil mudharabah. Pada masa inflasi, masyarakat akan menarik dana lebih banyak dari simpanannya untuk memenuhi kebutuhan, sehingga dana yang dihimpun perbankan akan menurun, diikuti penurunan dalam penyaluran pembiayaan perbankan (Muttaqiena, 2013: 181).

\section{Jumlah Uang Beredar}

Jumlah uang beredar di masyarakat dibedakan menjadi dua kategori yaitu uang beredar dalam arti sempit (M1) dan uang beredar dalam arti luas (M2). M1 terdiri dari uang kartal yang beredar dimasyarakat (tidak termasuk uang kartal di bank) ditambah dengan uang giral. M2 merupakan penjumlahan M1 dengan tabungan dan deposito berjangka atau disebut uang kuasi (Siamat, 2005: 93).

\section{Hubungan Jumlah Uang Beredar dengan Pembiayaan Perbankan}

Bertambahnya jumlah uang beredar memberi peluang bagi perbankan untuk melakukan fungsi intermediasi. Peningkatan jumlah uang beredar di masyarakat direspon perbankan syariah dengan peningkatan pembiayaan. Sebab, kenaikan jumlah uang beredar akan meningkatkan jumlah dana pihak ketiga yang dihimpun. Jika peningkatan dana pihak ketiga tidak segera disalurkan dalam pembiayaan, bank syariah akan mengalami kerugian akibat adanya kewajiban untuk memberikan nisbah terhadap DPK yang telah dihimpun (Tohari, 2010: 86).

\section{Pertumbuhan Ekspor}

Ekspor merupakan perdagangan dengan cara mengeluarkan barang dari dalam ke luar wilayah pabean Indonesia dengan memenuhi ketentuan yang berlaku (Rivai, Permata, \& Idroes, 2007: 321). Negara dengan perekonomian terbuka tidak terlepas dari perdagangan internasional. Faktor penentu ekspor dan impor adalah output suatu negara. Total pengeluaran dalam negeri disebut permintaan dalam negeri (jumlah konsumsi ditambah investasi dalam negeri ditambah pembelian oleh pemerintah untuk barang dan jasa).

Ekspor ke suatu negara berhubungan dengan pendapatan dan output negara tersebut. Apabila output luar negeri meningkat, nilai tukar terhadap mata uang negara lain menurun, maka volume dan nilai ekspor suatu negara cenderung meningkat. Penyebabnya adalah ketika perekonomian negara tumbuh dengan cepat dan harga-harga meningkat secara relatif terhadap mitra dagangnya, akibatnya ekspor cenderung lebih lambat dibandingkan impornya. Kemudian ketika perekonomian luar negeri tumbuh 
kurang cepat dibandingkan dengan perekonomian dalam negeri akang menurunkan ekspor, sementara impor tumbuh secara tajam. Akibatnya adalah perputaran besar ke arah defisit pada ekspor netto riil (Samuelson \& Nordhaus, 1997: 183).

\section{Hubungan Ekspor dengan Pembiayaan Syariah}

Kegiatan ekspor merupakan kegiatan untuk membangun ekonomi suatu negara yang lebih kuat, maju dan mandiri. Salah satu upayanya adalah mengembangkan kegiatan ekspor syariah melalui pembiayaan sektor riil yang berorientasi ekspor, baik pembiayaan modal kerja maupun investasi. Ketika sebuah negara dalam kegiatan ekspor mengalami peningkatan, maka pembiayaan ekspor juga mengalami peningkatan. Tujuan pemberian pembiayaan ekspor adalah untuk dapat membantu memperkuat permodalan dan diharapkan produk yang dihasilkan mempunyai daya saing di pasar ekspor (Agustianto, 2014).

\section{Dana Pihak Ketiga}

Menurut Kasmir (2004: 50), sumber dana bank adalah usaha bank dalam menghimpun dana dari masyarakat. Sedangkan menurut Rivai (2008: 213) dana pihak ketiga adalah dana yang diperoleh dari masyarakat baik individu, perusahaan, pemerintah, rumah tangga, koperasi, yayasan dan lain-lain dalam mata uang rupiah ataupun valuta asing. Menurut Kasmir (2004: 40) untuk memperoleh dana dari masyarakat luas, bank dapat menggunakan tiga macam jenis simpanan (rekening), yaitu: Simpanan Giro (penarikan simpanan hanya menggunakan cek dan bilyet), Simpanan tabungan (penarikan simpanan sesuai persyaratan yang ditetapkan oleh bank. Penarikan tabungan dilakukan menggunakan buku tabungan, slip penarikan, kuitansi, atau kartu Anjungan Tunai Mandiri (ATM), dan simpanan deposito (simpanan yang memiliki jangka waktu tertentu/jatuh tempo dan penarikannya dilakukan sesuai jangka waktu tersebut).

\section{Hubungan Dana Pihak Ketiga dengan Pembiayaan Perbankan}

Dana pihak ketiga merupakan dana yang dihimpun dari masyarakat luas dan menjadi sumber dana terpenting bagi operasi bank serta merupakan ukuran keberhasilan bank jika mampu membiayai operasinya dari sumber dana ini (Antonio, 2001:105). Penghimpunan dana pihak ketiga yang semakin tinggi akan mendorong peningkatan volume pembiayaan yang disalurkan (Faizal \& Prabawa, 2010: 54).

\section{Pembiayaan Perbankan Syariah}

Menurut Rivai (2008: 220), pembiayaan merupakan penyediaan uang atau tagihan yang dapat dipersamakan dengan itu, berdasarkan persetujuan atau kesepakatan pinjam meminjam antara lembaga keuangan pihak lain yang mewajibkan pihak peminjam untuk melunasi utangnya setelah jangka waktu tertentu, dengan imbalan atau bagi hasil. Menurut Rivai (2008: 220) beberapa penjelasan mengenai pembiayaan perbankan syariah, yaitu:

\section{Tujuan pembiayaan}

Tujuan pembiayaan, pada dasarnya mencakup dua fungsi yang saling berkaitan, yaitu: profitabilitas, merupakan tujuan untuk memperoleh hasil pembiayaan berupa keuntungan dari bagi hasil suatu usaha yang dikelola bersama nasabah. Safety, merupakan keamanan dari prestasi atau fasilitas yang diberikan, sehingga profitabili- 
ty dapat tercapai tanpa hambatan.

\section{Fungsi pembiayaan}

Menurut Rivai (2008: 220) secara garis besar fungsi pembiayaan dalam perekonomian yaitu pembiayaan dapat meningkatkan utility (daya guna) dari modal/ uang; meningkatkan daya guna suatu barang; meningkatkan peredaran dan lalu lintas uang; menimbulkan gairah usaha masyarakat; sebagai alat stabilitas ekonomi; sebagai jembatan peningkatan pendapatan nasional dan sebagai alat hubungan ekonomi internasional.

\section{Prinsip-Prinsip Pembiayaan}

Menurut Rivai (2008: 224) produk pembiayaan perbankan syariah terbagi dalam tiga kategori berdasarkan tujuan penggunaannya, yaitu:

\section{Prinsip Jual Beli (Ba'i)}

Prinsip ini dilaksanakan dengan perpindahan kepemilikan barang atau benda (transfer of property). Tingkat keuntungan bank ditentukan di depan dan menjadi bagian harga barang yang dijual. Transaksi jual beli dibedakan berdasarkan bentuk pembayaran dan waktu penyerahan barangnya, yakni:

a. Pembiayaan Murabahah, adalah transaksi jual beli dimana bank menyebut jumlah keuntungannya. Bank bertindak sebagai penjual sementara nasabah sebagai pembeli. Harga jual adalah harga beli bank dari pemasok ditambah keuntungan (marjin). Kedua belah pihak harus menyepakati harga jual dan jangka waktu pembayarannya. Harga jual dicantumkan dalam akad jual beli dan jika telah disepakati tidak dapat berubah selama akad. Dalam perbankan, pembayaran murabahah dilakukan dengan cicilan (bi tsaman ajil atau muajjal), sedangkan barang diserahkan segera setelah akad.

b. Pembiayaan salam, adalah transaksi jual beli di mana barang yang diperjualbelikan belum ada. Oleh karena itu barang diserahkan secara tangguh sedangkan pembayaran dilakukan secara tunai. Bank bertindak sebagai pembeli, sementara nasabah sebagai penjual.

c. Pembiayaan istishna, produk istishna menyerupai produk salam, namun dalam istishna pembayarannya dapat dilakukan oleh bank dalam beberapa kali pembayarannya. Skim istishna dalam bank syariah umumnya diaplikasikan pada pembiayaan manufaktur dan konstruksi.

\section{Prinsip Bagi Hasil (Syirkah)}

Menurut Antonio (2001), produk pembiayaan syariah yang berdasarkan prinsip bagi hasil adalah:

a. Pembiayaan Mudharabah (Trust Financing, Trust Investment), adalah sistem kerja sama usaha antara dua pihak atau lebih di mana pihak pertama (shahibul al-mal) menyediakan seluruh kebutuhan modal dan customer sebagai pengelola (mudharib) menyediakan keahliannya. Keuntungan usaha dibagi menurut kontrak, sedangkan rugi ditanggung oleh pemilik modal selama kerugian itu bukan akibat kecurangan atau kelalaian pengelola (customer). Jika diakibatkan oleh kecurangan atau kelalaian pengelola (customer), maka pengelola menanggung kerugian tersebut. 
b. Pembiayaan Musyarakah (Partnership, Project Financing Participation), karakterisiknya yaitu adanya keinginan dari para pihak (dua pihak atau lebih) melakukan kerjasama untuk suatu usaha tertentu. Masing-masing menyertakan dan menyetorkan modalnya (baik intangible asset maupun tangible asset) dengan pembagian keuntungan sesuai kesepakatan.

c. Pembiayaan al-muzara'ah (Harvest Yield Profit Sharing), diartikan sebagai kerja sama pengolahan pertanian antara pemilik lahan dan penggarap, di mana pemilik lahan memberikan lahan pertanian kepada penggarap untuk ditanami dan dipelihara dengan presentase imbalan tertentu dari hasil panen.

d. Al-Musaqah (Plantation Management Fee Based on Certain Portion of Yield), merupakan bentuk sederhana dari al-muzara'ah, di mana penggarap tanah hanya bertanggung jawab atas penyiraman dan pemeliharaan. Imbalanya penggarap memperoleh nisbah dari hasil panen.

\section{Prinsip Sewa-menyewa (Ijarah dan IMBT)}

Menurut Antonio (2001), Ijarah adalah akad untuk memanfaatkan jasa, baik jasa atas barang (sewa-menyewa) atau jasa atas tenaga kerja (upah-mengupah). Sedangkan ju'alah adalah akad ijarah yang pembayarannya berdasarkan kinerja objek yang disewa. Pada ijarah, tidak terjadi perpindahan kepemilikan objek ijarah. Namun dalam perkembangannya, peminjam (customer) dimungkinkan untuk memiliki objek ijarah di akhir periode peminjaman yang disebut sebagai Ijarah Muntahia Bittamlik (IMBT).

\section{Kerangka Pemikiran}

Kerangka pemikiran menunjukkan antara pengaruh variabel independen dengan variabel dependen. Variabel dependen dalam penelitian ini adalah Total Pembiayaan Perbankan Syariah (Y). Variabel independen terdiri dari Kurs Rupiah (X1), Laju Inflasi (X2), Jumlah Uang Beredar (X3), Pertumbuhan Ekspor (X4) dan dimoderasi oleh variabel Dana Pihak Ketiga (Z). Berdasarkan telaah pustaka dan perumusan hipotesis di atas, maka kerangka pemikiran yang melandasi penelitian ini dapat digambarkan sebagai berikut:

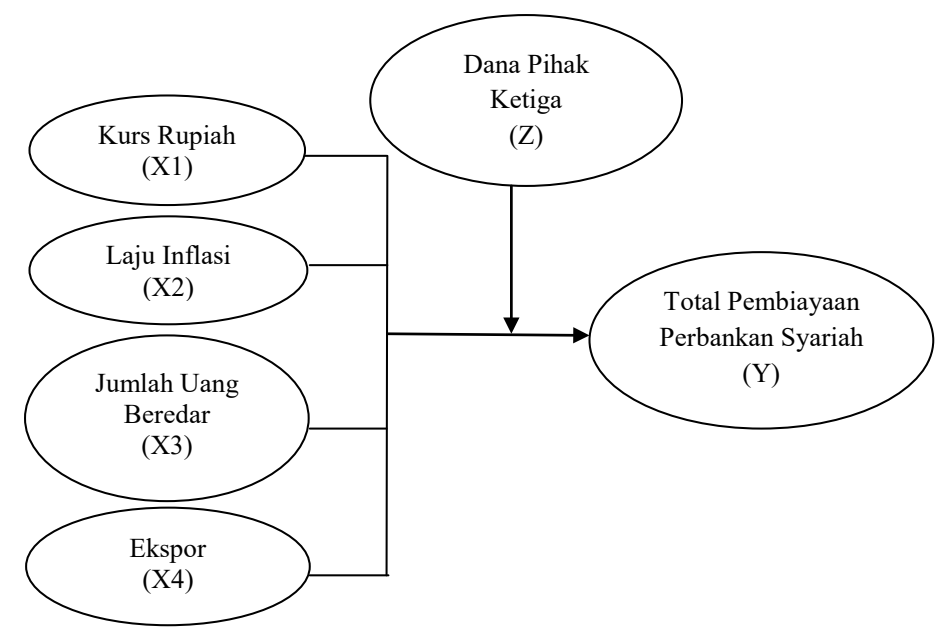

Gambar 1. Kerangka Penelitian 


\section{METODE PENELITIAN}

\section{Ruang Lingkup Penelitian}

Penelitian ini adalah penelitian kuantitatif yaitu penelitian dengan mengumpulkan data-data yang berupa angka (Martono, 2011: 20). Hal ini diperkuat pula dengan data time series (data yang diperoleh dan dikumpulkan dari waktu ke waktu (Supranto, 2000: 10). Sampel penelitian ini berupa data Inflasi, Kurs Rupiah, Jumlah Uang Beredar, Pertumbuhan Ekspor, Dana Pihak Ketiga dan Total Pembiayaan Perbankan Syariah. Metode penentuan sampel dengan teknik sampel jenuh, yaitu teknik penentuan sampel bila semua anggota populasi dipilih sebagai sampel (Martono, 2011: 79). Penelitian ini menggunakan data time series berupa data bulanan mulai Januari 2007 sampai Desember 2015. Data tersebut diperoleh dari dua sumber, yaitu Bank Indonesia (BI) dan Badan Pusat Statistik (BPS). Data yang digunakan dalam penelitian ini adalah data sekunder, yaitu data yang meliputi:

1. Data kurs rupiah, jumlah uang beredar dan pertumbuhan ekspor berasal dari laporan Statistik Ekonomi Keuangan Indonesia mulai bulan Januari 2007 hingga Desember 2015 yang dipublikasikan oleh Bank Indonesia.

2. Data DPK dan Total Pembiayaan Perbankan Syariah berasal dari laporan Statistik Perbankan Syariah yang di publikasikan oleh Bank Indonesia.

3. Data Inflasi diambil dari Badan Pusat Statistik (BPS) yang dipublikasikan.

\section{Metode Analisis Data}

Analisis data yang digunakan dalam penelitian ini adalah regresi berganda dengan data multivariate untuk meguji pengaruh variabel independen terhadap dependen. Penelitian ini menggunakan asumsi klasik sebelum olah data. Untuk pengujian variabel moderasi dengan menggunakan uji residual.

\section{Analisis Data}

Tabel 2. Uji Statistik Deskriptif

\begin{tabular}{lrrrrr}
\hline & $\mathrm{N}$ & Minimum & Maximum & Mean & Std. Deviation \\
\hline KURS & 108 & $8,481.00$ & $14,654.00$ & $10,238.4537$ & $1,544.03993$ \\
INFLASI & 108 &, 0241 &, 1214 &, 062398 &, 0220193 \\
JUB & 108 & 190496,00 & 4508603,00 & $1,8980 \mathrm{E} 6$ & $1,64004 \mathrm{E} 6$ \\
EKSPOR & 108 & 7424591,00 & 18530803,00 & $1,3299 \mathrm{E} 7$ & $2,65067 \mathrm{E} 6$ \\
DPK & 108 & 20514,00 & 231175,00 & 105458,6204 & 69494,69507 \\
PEMBIAYAAN & 108 & 20218,00 & 212996,00 & 103169,3241 & 67553,63980 \\
Valid N (list- & 108 & & & & \\
wise) & & & & & \\
\hline
\end{tabular}

Sumber: Data sekunder yang diolah

Berdasarkan output data di atas, rata-rata total pembiayaan perbankan syariah sebesar Rp 103.169,3241 Miliar dan standar deviasi Rp 67.553,63980 Miliar. Sedangkan rata-rata kurs bulanan dari tahun 2007-2015 sebesar Rp 10.238,4537; ratarata inflasi sebesar 0,062398; rata-rata jumlah uang beredar sebesar Rp1.898.045 
Miliar; rata-rata ekspor sebesar Rp 105.458,6 dan rata-rata dana pihak ketiga sebesar Rp 105.458,6.

Hasil uji normalitas, diperoleh Asymp. Sig. (2-tailed) yaitu sebesar 0.464. Nilai tersebut lebih besar dari pada 0.05 . Hal ini dapat disimpulkan bahwa data berdistribusi normal. Dari hasil uji heteroskedastisitas dapat diketahui nilai $\mathrm{R}^{2}$ sebesar 0,996 , maka kita dapat mengetahui besarnya $\mathrm{X}^{2}$ hitung yaitu $0,996 * 108=107,568$ dan besarnya $\mathrm{X}^{2}$ tabel adalah 124,3420 . Karena $\mathrm{X}^{2}$ hitung $<\mathrm{X}^{2}$ tabel maka gejala heteroskedastisitas dalam model persamaan tidak ada.

Hasil pengolahan data diperoleh nilai DW 1,972, nilai ini akan dibandingkan dengan tabel DW dengan jumlah observasi $(n)=108$, jumlah variabel $(k)=5$ dan tingkat signifikansi 0,05 didapat nilai $\mathrm{dl}=1,571$ dan nilai $\mathrm{du}=1,780$. Karena nilai DW di atas nilai du (1,780) dan di bawah 4-du $(2,22)$, maka dapat disimpulkan bahwa tidak ada autokorelasi dalam model regresi.

Hasil uji sebelumnya menunjukkan terdapat penyakit multikolinearitas, untuk mengatasi masalah ini perlu mengilangkan salah satu variabel bermasalah yaitu variabel dana pihak ketiga. Setelah menghilangkan variabel dana pihak ketiga, dapat dilihat bahwa tidak ada variabel independen yang memiliki nilai Tolerance Value kurang dari 0.10 dan VIF lebih dari 10. Maka dapat disimpulkan tidak ada multikoliniearitas dalam model regresi.

\section{Pengujian Hipotesis Pertama}

Berdasarkan hasil uji, maka model regresi berganda antara variabel independen dan variabel dependen dapat dirumuskan sebagai berikut:

Pembiayaan $=-4056,344-0.496$ Kurs $+89335,054$ Inflasi

$$
-0,004 \mathrm{JUB}+0,000 \text { Ekspor }
$$

Nilai Koefisien determinasi $\left(\mathrm{R}^{2}\right)$ sebesar 0.692 artinya bahwa kontribusi variabel independen mempengaruhi variabel dependen sebesar $69,2 \%$, sedangkan sisanya $30,8 \%$ dijelaskan oleh variabel lain di luar model. Sedangkan uji $\mathrm{F}$ menghasilkan nilai $F$ sebesar 4793,540 dan sig $0.000 \leq 0.05$. Hal ini menunjukkan bahwa variabel kurs, inflasi, JUB, ekspor dan DPK secara simultan berpengaruh signifikan terhadap total pembiayaan perbankan syariah di Indonesia tahun 2007-2015. Sementara uji t menunjukkan bahwa:

1. Variabel kurs rupiah bernilai negatif pada t hitung sebesar $-0,553$ dengan nilai signifikasi 0,582. Karena nilai signifikasi kurs rupiah 0,582 lebih besar dari 0,05 dan memiliki koefisien bernilai negatif yaitu -0,496 maka dapat disimpulkan bahwa kurs tidak berpengaruh signifikan terhadap total pembiayaaan perbankan syariah di Indonesia tahun 2007-2015.

2. Variabel inflasi bernilai positif pada thitung sebesar 4,052 dengan nilai signifikasi 0,000. Karena nilai signifikasi inflasi 0,000 lebih kecil dari 0,05 dan memiliki koefisien bernilai positif yaitu 89335,054 maka dapat disimpulkan bahwa inflasi berpengaruh secara signifikan dan positif terhadap total pembiayaan perbankan syariah di Indonesia tahun 2007-2015.

3. Variabel JUB bernilai positif pada t hitung 4,086 dengan nilai signifikani 0.000 . Karena nilai signifikasi JUB 0.000 lebih besar dari 0.05 dan memiliki koefisien bernilai positif yaitu 0,004 maka dapat disimpulkan bahwa JUB berpengaruh 
secara signifikan dan positif terhadap total pembiayaan perbankan syariah di Indonesia tahun 2007-2015.

4. Variabel ekspor bernilai positif pada thitung 1,191 dengan nilai signifikasi 0,236. Karena nilai signifikasi ekspor 0,236 lebih besar dari 0,05 dan memiliki koefisien bernilai positif yaitu 0,000 maka dapat disimpulkan bahwa ekspor tidak berpengaruh signifikan terhadap total pembiayaan perbankan syariah di Indonesia tahun 2007-2015.

\section{Pengujian Hipotesis Kedua}

Pengujian variabel moderating menggunakan uji residual guna mengatasi multikolinieritas (Ghozali, 2013: 239). Berdasarkan hasil uji statistik diketahui bahwa tidak semua variabel independen dimoderasi oleh Dana Pihak Ketiga. Berikut hasil uji regresi moderasi dan interpretasinya:

1. Dana Pihak Ketiga Memoderasi Pengaruh Kurs Rupiah Terhadap Total Pembiayaan Perbankan Syariah di Indonesia.

Nilai signifikansi kurs rupiah sebesar $0.017<0.05$ dengan koefisien sebesar -0.229, sehingga dikatakan bahwa DPK memoderasi pengaruh kurs rupiah terhadap total pembiayaan perbankan syariah di Indonesia. Dengan demikian hipotesis pertama (H1b) diterima yaitu dana pihak ketiga memoderasi pengaruh kurs rupiah terhadap total pembiayan perbankan syariah di Indonesia. Ketika kurs rupiah terhadap dolar AS naik, maka produksi barang dan jasa yang dihasilkan negara tersebut akan menjadi mahal bila dihitung dengan mata uang negara lain. Akibatnya permintaan terhadap barang atau jasa akan mengalami penurunan dan tidak tertutup kemungkinan adanya penggunaan substitusi yang dapat menekan permintaan. Permintaan yang menurun akan disikapi oleh produsen dengan menurunkan pasokan sehingga tercapai keseimbangan baru. Pengurangan pasokan dilakukan dengan mengurangi produksi yang dapat menurunkan pendapatan masyarakat. Akibatnya dana yang tersedia untuk diinvestasikan dan disimpan akan berkurang, sehingga bank kesulitan melakukan penghimpunan dana pihak ketiga. Kemudian berimplikasi pada penyaluran pembiayaan perbankan syariah berkurang, karena dana yang dimiliki oleh perbankan syariah kurang mencukupi untuk disalurkan ke masyarakat atau pelaku usaha.

2. Dana Pihak Ketiga Memoderasi Pengaruh Inflasi Terhadap Total Pembiayaan Perbankan Syariah di Indonesia.

Nilai signifikansi Inflasi adalah $0.0000<0.05$ dengan koefisien sebesar 0.336, sehingga dikatakan bahwa DPK memoderasi pengaruh inflasi terhadap total pembiayaan perbankan syariah di Indonesia. Dengan demikian hipotesis kedua $(\mathrm{H} 2 \mathrm{~b})$ diterima yaitu dana pihak ketiga memoderasi hubungan inflasi terhadap total pembiayan perbankan syariah di Indonesia. Menurut Bank Indonesia (2007) kenaikan inflasi akan direspon oleh Bank Indonesia dengan menaikkan suku bunga SBI, hal ini juga menyebabkan kenaikan suku bunga perbankan baik suku bunga DPK maupun pembiayaan. Kenaikan suku bunga DPK mengakibatkan naiknya DPK sehingga likuiditas perbankan meningkat. Peningkatan likuiditas ini berarti bahwa inflasi berpengaruh positif dan signifikan terhadap pembiayaan perbankan syariah. Artinya, apabila terjadi kenaikan inflasi, maka jumlah pembiayaan perbankan syariah akan mengalami kenaikan, begitu juga sebalikya. Peningkatan likuiditas ini berarti meningkatkan kemampuan dan kapasitas perbankan untuk menyalurkan pembiyaan atau 
meningkatkan penawaran pembiayaan kepada masyarakat.

3. Dana Pihak Ketiga Memoderasi Pengaruh Jumlah Uang Beredar Terhadap Total Pembiayaan Perbankan Syariah di Indonesia.

Nilai signifikansi Jumlah Uang Beredar adalah $0.152>0.05$ dengan nilai koefisien sebesar -0.139 , sehingga dikatakan bahwa DPK tidak dapat memoderasi pengaruh antara JUB dengan pembiayaan perbankan syariah. Dengan demikian hipotesis ketiga (H3b) ditolak yaitu dana pihak ketiga memoderasi hubungan jumlah uang beredar terhadap total pembiayan perbankan syariah di Indonesia. Hal ini dikarenakan ketika perekonomian negara sedang lesu, maka Bank Indonesia memiliki tugas untuk mengontrol perekonomian dengan melakukan kebijakan moneter ekspansif. Pada saat Bank Indonesia melakukan kebijakan ekspansif dengan menurunkan BI rate, maka akan diikuti penurunan tingkat suku bunga SBI. Tingkat suku bunga SBI yang menurun secara otomatis akan mengurangi keuntungan bank-bank lain yang memiliki SBI, sehingga bank-bank tersebut akan menurunkan suku bunga tabungan. Dana beralih ke masyarakat karena banyak yang menarik uangnya dari perbankan, akibatnya jumlah uang beredar meningkat diikuti peningkatan keinginan belanja masyarakat, sehingga dana yang dimiliki seseorang cenderung digunakan untuk berbelanja dibandingkan menabung.

4. Dana Pihak Ketiga Memoderasi Pengaruh Pertumbuhan Ekspor Terhadap Total Pembiayaan Perbankan Syariah di Indonesia.

Nilai signifikansi Pertumbuhan Ekspor adalah $0.0000<0.05$ dengan nilai koefisien sebesar 0.501 , sehingga dikatakan bahwa DPK memoderasi pengaruh pertumbuhan ekspor terhadap total pembiayaan perbankan syariah di Indonesia.Dengan demikian hipotesis keempat (H4b) diterima yaitu dana pihak ketiga memoderasihubungan pertumbuhan ekspor terhadap total pembiayan perbankan syariah di Indonesia. Ketika ekspor suatu negara meningkat, maka pertumbuhan ekonomi di negara tersebut sedang mengalami peningkatan. Peningkatan perekonomian negara akan diimbangi oleh meningkatnya pendapatan masyarakat, kemudian pemenuhan kebutuhan hidupnya dapat terpenuhi (Samuelson dan Nordhaus, 1997: 180). Sebagian masyarakat yang mampu dalam segi material akan menyisihkan uangnya untuk dialokasikan ke bank, baik untuk motif berjaga-jaga atau investasi. Kemudian penghimpunan dana bank akan meningkat, sehingga dapat disalurkan sebagai modal pembiayaan untuk masyarakat atau pelaku usaha.

\section{PENUTUP}

Berdasarkan hasil penelitian, maka dapat dinyatakan bahwa kurs rupiah berpengaruh negatif dan tidak signifikan terhadap total pembiayaan perbankan syariah di Indonesia. Sedangkan inflasi, jumlah uang beredar, pertumbuhan ekspor dan dana pihak ketiga berpengaruh positif dan signifikan terhadap total pembiayaan perbankan syariah di Indonesia. Jika dilihat dari sisi variabel moderator, maka variabel dana pihak ketiga dapat memoderasi pengaruh antara kurs rupiah, inflasi dan pertumbuhan ekspor terhadap total pembiayaan perbankan syariah di Indonesia. Namun, variabel dana pihak ketiga tidak memoderasi pengaruh antara jumlah uang beredar terhadap total pembiayaan perbankan syariah di Indonesia. 


\section{DAFTAR PUSTAKA}

Agustianto. (2014). Pembiayaan Ekspor Syariah. Dipetik September 21, 2016, dari http:// www.dakwatuna.com

Antonio, Muhammad Syafi'i. (2001). Bank Syariah dari Teori ke Praktik. Jakarta: Gema Insani.

Cahyono, Ari. (2009). Pengaruh Indikator Makroekonomi terhadap Dana Pihak Ketiga dan Pembiayaan Bank Syariah Mandiri. Tesis. Pascasarjana Fakultas Ekonomi Universitas Indonesia. Jakarta

Faizal, A. \& Prabawa, S. A. (2010). Analisis Pengaruh Total Aset, Dana Pihak Ketiga, dan Non Performing Financing (NPF) terhadap Volume Pembiayaan Bagi Hasil (Studi Kasus Pada Bank Umum Syariah Devisa). Jurnal Ilmiah Manajemen, 8(1).

Gerai Info BI. (t.thn.). Diambil kembali dari Bank Indonesia: http://www.bi.go.id

Ghozali, Imam. (2013). Aplikasi Analisis Multivariate Dengan Program IBM SPSS 19. Semarang: Badan Penerbit Universitas Diponegoro

Halim, Levina. (2013). Pengaruh Makroekonomi dan Ekspor Terhadap Kredit Modal Kerja dan Kredit Invetasi Perbankan. FINESTA, 1(2), 1-6.

Halwani, Hendra. (2005). Ekonomi Internasional \& Globalisasi Ekonomi Edisi Kedua. Bogor: Ghalia Indonesia.

Herijanto, Hendy. (2013). Selamatkan Perbankan. Bandung: PT Mizan Publika.

Setiawan, Sakina RD. (2016). Ini Tantangan Terbesar Perbankan di tahun 2016. Dipetik Agustus 5, 2016, dari Kompas.com: http://ekonomi.kompas.com

Junaedi, Dedi. (2015). “Solusi Permanen Mengatasi Krisis Rupiah”, dalam majalah Gontor Media Perekat Umat Edisi 20 April-18 Mei 2015.

Karim, Adiwarman. (2007). Ekonomi Makro Islam. Jakarta: PT Raja Grafindo Persada.

Kasmir. (2004). Pemasaran Bank. Jakarta: Prenada Media.

Lie, W. \& Malelak, M. I. (2015)."Pengaruh Makroekonomi Terhadap Kredit Perbankan di Indonesia Periode 2007-2014”. FINESTA. 3(2), 67-72.

Mankiw, N Gregori. (2000). Pengantar Ekonomi Jilid Dua. Jakarta: Erlangga.

Martono, Nanang. (2011). Metode Penelitian Kuantitatif. Jakarta: PT Raja Grafindo Persada.

Muttaqiena, Abida (2013). Analisis Pengaruh Produk Domestik Bruto, Inflasi, Tingkat Bunga, Dan Nilai Tukar Terhadap Dana Pihak Ketiga Perbankan Syariah Di Indonesia Tahuin 2008-2012. Jurnal Ekonomi Pembangunan.

Rivai, Veithzal. (2008). Islamic Financial Management. Jakarta Utara: PT Raja Grafindo Persada.

Rivai, V., Andria, P., \& Idroes, F. N. (2007). Bank and Financial Institution Management (Conventional \& Sharia System). Jakarta: PT Raja Grafindo Persada.

Samuelson, P. A \& Nordhaus. W. D. (1997). Makro Ekonomi Edisi Keempatbelas. Jakarta: Erlangga.

Setiawan, I. \& Baratakusumah, S. D. (2005). Pengaruh Konsumsi Investasi, Jumlah Uang Beredar Dan Inflasi Terhadap Penentuan Kebijakan Suku Bunga SBI. Jurnal Universitas Esa Unggul.

Siamat, Dahlan. (2005). Manajemen Lembaga Keuangan Edisi Kelima. Jakarta: LPFE UI.

Sukirno, Sadono. (1999). Makroekonomi Modern. Jakarta: PT Raja Grafindo Persada.

Supranto. (2000). Statistik (teori dan Aplikasi) Edisi ke enam jilid 1. Jakarta: Erlangga.

Suryowati, E. (2016). Pertumbuhan Ekonomi Kuartal II 2016 capai 5,18 persen. Dipetik Agustus 31, 2016, dari Kompas.com: http://ekonomi.kompas.com

Tohari, Achmad. (2010). Analisis Pengaruh Nilai Tukar Rupiah terhadap Dollar, Inflasi, dan Jumlah Uang Beredar (M2) terhadap Dana Pihak Ketiga (DPK) serta Implikasi pada Pembiayaan Mudharabah (pada Perbankan Syariah di Indonesia). Skripsi. 
Tangerang: Universitas Islam Negeri Syarif Hidayatullah.

Untoro. (2007). Mengkaji Evektivitas Penggunaan Arima dan VAR dalam Melakukan Proyeksi

Permintaan Uang Kartal di Indonesia. Buletin Eknomi Moneter dan Perbankan, 10(1). 